\title{
Adventures in Direct Democracy: The Top Ten Constitutional Lessons from the California Recall Experience
}

\author{
Vikram David Amar†
}

California conducted an extraordinary exercise in self-government last fall. For the first time in the state's history, a gubernatorial recall measure qualified for a statewide general election. After a litigation roller coaster that came close to derailing the election for months, voters, on October 7 , 2003, confronted a two-part ballot. The first part (Part One) asked whether Governor Gray Davis should be recalled from his four-year term (which had begun after his reelection in November 2002). The second part (Part Two) asked which candidate should replace him should he get fewer than $50 \%$ of the votes on the first question. When the votes were tallied, Davis had been ousted, and Arnold Schwarzenegger had been elected as his successor.

Copyright C 2004 California Law Review, Inc. California Law Review, Inc. (CLR) is a California nonprofit corporation. CLR and the authors are solely responsible for the content of their publications.

$\dagger \quad$ Professor of Law, University of California, Hastings College of the Law; Visiting Professor of Law, School of Law, University of California, Berkeley (Boalt Hall). The author wishes to thank Evan Lee, David Jung, Beth Garrett, Keenan Kmiec, John Yoo, Richard Hasen, Eugene Volokh, Erwin Chemerinsky, Dan Lowenstein, and Larry Tribe for reading and commenting on early drafts of this essay.

The author preliminarily explored some of the issues raised in this piece in a series of Findlaw.com columns and newspaper op-eds last year. See Vikram Amar, A Chance to Judge the Judges, SAN JosE Mercury News, Sept. 28, 2003, at 1P; Vikram David Amar, The Ninth Circuit May Stand Unjustly Accused, L.A. Times, Sept. 11, 2003, at B 17; Vikram David Amar, Governor Davis's Claim to Run as His Own Successor Is Meritless, But the Fear of a "Fringe" Winner Is Serious: How the Risk Can Be Eliminated in the Future, Findlaw.com (Aug. 8, 2003), at http://writ.news.findlaw.com/amar/ 20030808.html; Vikram David Amar, Reflections on the California Recall: The Lingering Questions Over Its Legitimacy, And Its Basis in the California Constitution, Findlaw.com (Oct. 17, 2003), at http://writ.news.findlaw.com/amar/20031017.html; Vikram David Amar, The Ruling Postponing the California Recall Eleetion: Why It Is Questionable, and Why It Was Not Compelled by Bush v. Gore, Findlaw.com (Sept. 19, 2003), at http://writ.news.findlaw.com/amar/20030919.html; Vikram David Amar \& Alan E. Brownstein, A Mixed Verdict on the California Supreme Court's Decision, Findlaw.com (Aug. 22, 2003), at http://writ.news.findlaw.com/amar/20030822.htrnl; Vikram David Amar \& Alan Brownstein, Why an Important Part of the California Recall Process is Unconstitutional, According to U.S. Supreme Court Precedent, Findlaw.com (July 25, 2003), at http://writ.news.findlaw.com/amar/20030725.html. 
Legal analysts and political scientists have tried for months now to place October's experience into perspective. In the pages that follow, I too attempt to do so with respect to the myriad of constitutional questions raised by and during the recall. With all apologies to David Letterman, with whom I could never compete, ${ }^{1}$ here is my list of the Top Ten constitutional lessons that the episode teaches us.

10.

The Recall Demonstrates the Continuing, Unfortunate

Consequences of a Recent, Poorly Reasoned Ruling by a Divided Supreme Court Concerning How People Get "Counted" in a Statewide Election.

No, I am not talking about Bush v. Gore ${ }^{2}$ (I will discuss that case later on in this Essay). Here, I am referring to Buckley v. American Constitutional Law Foundation ${ }^{3}$ (ACLF), a 1999 ruling by the Supreme Court addressing a challenge to Colorado's initiative procedures. Colorado law provided that when a certain number of voters sign up in support of a given state initiative, the measure is placed on the statewide ballot. ${ }^{4}$ In $A C L F$, the Court reviewed and invalidated three particular Colorado regulations governing this process. First, Colorado required that each signature gatherer wear a badge bearing her name and indicating whether or not she was paid to collect the signatures. Second, each gatherer had to be a registered Colorado voter. Third, initiative backers had to disclose monthly exactly how much each gatherer was getting paid.

The Supreme Court, in a five-person opinion authored by Justice Ginsburg (with Justice Thomas concurring in the judgment), struck down each of these provisions as violating the right to "petition" government protected by the First and Fourteenth Amendments. The Court held that circulating an initiative petition is akin to distributing a handbill, and that Colorado's identity badge requirement was thus squarely foreclosed by a

1. Letterman's Top Ten lists—even those concerning the California recall—are undoubtedly better than mine. My favorite might be the list presented the night after Schwarzenegger was elected, entitled "Top Ten Ways California Would Be Different If I, Gary Coleman, Had Been Elected Governor." Late Show with David Letterman (CBS television broadcast, Oct. 8, 2003), available at http://www.cbs.com/latenight/lateshow/top_ten/archive/ls_topten_archive2003/ls_topten_archive_2003 I008.shtml. Number Two on the list was: "I would form a task force to find out exactly what Willis was talking about." Id.

2. 531 U.S. $98(2000)$.

3. 525 U.S. 182 (1999).

4. Id. at I86 (referencing Colo. Const. art. V, $\S$ I (1)-(2); Colo. Rev. STat. $\$ \S 1-40-10$ I to $-133($ I 998$)$ ). 
1995 ruling $^{5}$ in which the Court struck down an Ohio law banning the anonymous distribution of campaign handbills. ${ }^{6}$

Colorado's other rules met a similar fate. First, the Court found that requiring signature gatherers to be registered voters impermissibly limited the number of voices in the debate. ${ }^{7}$ Then it held that the financial disclosure requirements impermissibly forced paid gatherers and their backers to surrender the anonymity enjoyed by their volunteer counterparts. ${ }^{8}$ Both rulings relied on Meyer $v$. Grant, ${ }^{9}$ an earlier case in which the Court invalidated another Colorado initiative provision which attempted to prohibit the payment of money to initiative signature gatherers altogether. As in $A C L F$, the Court in Meyer characterized the question as "involv[ing] a limitation on political expression subject to exacting scrutiny." 10 From there, the Court quickly concluded that "[t]he refusal to permit appellees to pay petition circulators restricts political expression ... [and that] [t]he First Amendment protects appellees' right not only to advocate their cause but also to select what they believe to be the most effective means for so doing." "11

The Court's reasoning in these cases seems plausible if plaintiffs were "petitioning" within the meaning of the First Amendment. But that label is inapt. The Colorado initiative process is not about "petitioning the Government for a redress of grievances." 12 It is about circumventing government by engaging in lawmaking itself. Thus, state law did not regulate "petitions" or "speech" at all. Instead, it merely provided that unless signatures were collected in a certain way, they would not count for purposes of qualifying an initiative for the statewide ballot.

In effect, citizens retained the right to collect signatures and present them to the government as a demonstration of the signers' viewsessentially as a handbill. None of the challenged provisions of Colorado law said otherwise. This right, however, does not include the right to have signatures count for purposes of triggering an election when they do not comply with the ballot access rules Colorado has put in place. No court would deny that I have the right to voice my preference for Schwarzenegger for President, but I do not have a right to have my vote for

5. Mclntyre v. Ohio Elections Comm'n, 514 U.S. 334 (1995).

6. 525 U.S. at 199. Indeed, the $A C L F$ Court was actually unanimous in its invalidation of Colorado's identity badge provision. See $i d$. at 209, 217, 232.

7. Id. at 197.

8. Id. at 203-04.

9. 486 U.S. 414 (1988).

10. Id. at 420 .

11. Id. at 422-24.

12. See U.S. Const. amend. I. 
Schwarzenegger count when that vote is made six months before the presidential election and for a person ineligible to hold the office. ${ }^{13}$

Indeed, the Supreme Court has repeatedly made clear that contentneutral, reasonable ballot access requirements designed to limit the number of candidates or the number and complexity of issues placed on a ballot are not subject to strict judicial scrutiny. ${ }^{14}$ If the Court in ACLF (and Meyer) had seen the Colorado laws for what they were-ballot access rules-and not for what they were not-impediments to pure speech-then the Court likely would have come out the other way. It would have evaluated Colorado law, not with reference to the First Amendment's protection of core political speech, but with reference to the Tenth Amendment's protections, buttressed by those provided by the so-called Republican Guarantee Clause, ${ }^{15}$ of the core right of the people of each state to structure their lawmaking processes as they desire, so long as they do not discriminate on the basis of viewpoint, race, or some other illicit criterion. ${ }^{16}$

How does all this bear on California's recent recall experience? Precisely in this way: the biggest recurring objection to California's current recall structure is that the statewide ballot qualifications are too easy. ${ }^{17}$ The California constitution provides that "[a] petition to recall a statewide officer must be signed by electors equal in number to 12 percent of the last vote for the office, with signatures from each of 5 counties equal in number to 1 percent of the last vote for the office in the county." 18 This $12 \%$ threshold is significantly lower than those existing in other states that allow for gubernatorial recall ${ }^{19}$ and may account for the ease with which the Davis recall initiative qualified.

13. Cf. Akhil Reed Amar, The Five-Legged Dog: The Supreme Court Should See Through Mislabeled Argumentation, AM. LAW., Sept. 1999, at 47. Schwarzenegger is ineligible to thc Presidency because he is not a "natural born" U.S. citizen. See U.S. CoNST. art. Il, § 1, cl. 4.

14. See, e.g., Burdick v. Takushi, 504 U.S. 428, 439 (1992); Anderson v. Celebrezze, 460 U.S. 780, 792-93 (I983); Lubin v. Panish, 4I5 U.S. 709, 7 I 5 (1974); Bullock v. Carter, 405 U.S. 134, 14445 (1972).

15. U.S. ConST. art. IV, §4. See generally Vikram David Amar, The People Made Me Do It: Can the People of the States Instruct and Coerce Their State Legislatures in the Article V Constitutional Amendment Process?, 41 WM. \& MARY L. Rev. 1037, 1063-64 (2000); William T. Mayton, Direct Democracy, Federalism \& the Guarantee Clause, 2 GREEN BAG 2d 269, 270-72 (1999).

16. Obviously things would be different if a state structured its lawmaking process so that signatures of Democrats counted more than those of Republicans or signatures of whites eounted more than those of blacks. See Vikram D. Amar \& Evan H. Caminker, Equal Protection, Unequal Political Burdens, and the CCRI, 23 HASTINGS Const. L.Q. 1019 (1996); cf. Washington v. Seattle Sch. Dist. No. 1, 458 U.S. 457 (1982); Hunter v. Erickson, 393 U.S. 385 (1969).

17. See, e.g., Richard Hasen, Learning from the California Recall Experience: What the Unprecedented Election Tells Us About Our Laws Governing Politics, Findlaw.com (Oct. 13, 2003), at http://writ.news.findlaw.com/commentary/20031013_hasen.html.

18. CAL. CoNST. art. II, § I4(b).

19. See, e.g., Elizabeth Garrett, Democracy in the Wake of the California Recall, 152 U. PA. L. REv. (forthcoming 2004) (noting that Califomia's signature threshold is the "lowest in the nation" and that the "norm" for signatures is $25 \%$ of the number of people who voted at the previous election). 
But the $12 \%$ requirement is not the only requirement imposed upon the process by the people of California. Like Colorado, California also attempted to regulate the process of signature gathering. Section 11045 of California's Election Code, for example, provides that "[o]nly registcred voters of the electoral jurisdiction of the officer sought to be recalled are qualified to circulate ... a recall petition for that officer." ${ }^{20}$ This provision was (properly) assumed by recall litigants to be invalid under $A C L F^{21}$

A separate provision in California law imposed an additional restraint. To encourage a maximum number of voters to take a position on the first part of the recall ballot (so that a majority vote to recall would reflect a broad consensus of unfitness), California refused to count anyone's vote for a successor candidate on the second part of the ballot unless the voter had voted one way or the other on the recall question. ${ }^{22}$ But a federal court invalidated this provision as well in a lawsuit filed early during the recall campaign. ${ }^{23}$ And most any limitation California might try to adopt to regulate the payment of signature gatherers will likely be unenforceable by virtue of the $A C L F$ and Meyer rulings.

There are, to be sure, some changes the people of California can make if they are worried, as perhaps they should be, that the current provisions, combined with constraints imposed by Supreme Court cases, make it too easy for a recall to qualify for the ballot. For example, the $12 \%$ signature threshold for qualification could be raised, say to $20 \%$ or $25 \%$. Or perhaps California could require that before a governor is recalled, a supermajority-say, $55 \%$ or $60 \%$ of the voters rather than the current $50+\%$-must vote in favor of ouster. As another option, the recall provisions of the California constitution could provide for a substantive standard identifying

20. Cal. Elec. Code $§ 11045$ (West 2003)

21. A lawsuit filed in mid-July in state court by an anti-recall group against Secretary of State Kevin Shelley tried to enforce other requirements imposed by California law on signature gatherers. See Michael Finnegan \& Richard Simon, Davis Calls Recall a Bid to Hijack Government, L.A. TimEs, July 17, 2003, at A1. Plaintiffs in this lawsuit never clearly established any violations of these other requirements by signature gatherers. And even if they had, the trial court judge indicated at a hearing that the appropriate remedy might be not to discount the signatures gathered, but rather simply to punish any gatherers who violated the law. From the point of view of common sense and the First Amcndment, this seems to get things exactly backwards.

22. Cal. Elec. Code $\$ 11382$ (West 2003).

23. See Partnoy v. Shelley, 277 F. Supp. 2d 1064 (S.D. Cal. 2003) (mem.) (memorandum decision and order granting motion on the pleadings declaring California Elections Code section 11382 unconstitutional). Onc disappointing aspcct of this district court litigation was the severability analysis-that is, how much the rest of the statutory recall scheme is affected by section 11382's invalidity. In particular, a question was raised-but not adequately addressed-about whether people who voted for a successor on Part Two of the ballot, but who failed to cast a vote either way on Part One of the ballot, should be considered as having voted "No" on the recall itself. Cf. id. at 1081-87. Lingcring and troubling questions about this severability issue could have loomed large had the recall election been a close one. 
only certain grounds on which a recall may be based, ${ }^{24}$ in the way that the California and federal constitutions do for the impeachment of officers. ${ }^{25}$

But each of these options comes at a cost. For example, a high signature threshold may make success impossible for grassroots campaigns. That is, perhaps the $12 \%$ number would be a good one if people were not able effectively to buy signatures and use non-community members ${ }^{26}$ to collect them. Ironically enough, if we try to make it more difficult for the rich to buy access to a recall election, we may end up reserving the recall device only for the ultra rich.

The short of it is that California should not be put to such difficult choices. The Supreme Court should remcmber that the First and Fourteenth Amendments are not its only darlings. The Tenth Amendmont, which reserves powers to the states, is too. When these provisions appear to conflict, the Court should be more careful when determining which most appropriately applies.

9.

State Election Laws Enacted Before the 1960s SHOULd Be Revisited.

The lawsuits filed during the recall campaign in which California statutes were invalidated reveal a broader problem. They indicate that the "rights revolution" initiated by the Supreme Court of the 1960s has wreaked havoc on preexisting state election law regimes. Beginning with the "one-person, one-vote" cases, ${ }^{27}$ extending through cases recognizing voting as a "fundamental right" 28 and regulating state initiative processes, ${ }^{29}$ and culminating in Bush v. Gore, the Court has made the constitutional law of elections complicated and technical. Whcreas fifty years ago states could effectively insulate their elections from challenge, today a surprisingly large number of state election provisions are open to plausible federal constitutional attack. Indeed, in addition to the many federal claims and theories that were advanced in court during the recall, which included constitutional and Voting Rights Act challenges to the punch-card ballot machines, as well as the claim that Davis's supporters had a federal

24. Perhaps the state could then require signature gatherers to include the substantive grounds provision in any petitions they ask persons to sign. While the adequacy of the particular reasons behind a given recall effort perhaps should never be reviewable by the Secretary of State who accepts the signatures, see CAL. CoNST. art. II, $\$ 14(a)$, or by a court, the specification of permissible bases for a recall in the petitions themselves might make some would-be signers a bit more thoughtful.

25. See U.S. Const. art. II, § 4; CAL. Const. art. IV, § I8.

26. The Court in $A C L F$ suggests, but does not hold, that even a state residency requirement (apart from a requirement that a gatherer be a registered in-state voter) may be problematic. See Buckley v. Am. Constitutional Law Found., Inc., 525 U.S. I82, 197 (1999).

27. See, e.g., Reynolds v. Sims, 377 U.S. 533 (1964); Baker v. Carr, 369 U.S. 186 (I962).

28. See, e.g., Harper v. Virginia State Bd. of Elections, 383 U.S. 663 (I966).

29. See, e.g., Buckley, 525 U.S. at I82. 
constitutional right to have his name appear as a candidate on the second half of the ballot, there were many other nonfrivolous federal claims that were considered but ultimately not pursued. ${ }^{30}$

On top of all the ambiguity created by newly discovered federal constraints, many state election law codes-including California's-raise a tangled mess of unanswered state law questions. In the present episode, for example, there were questions about whether the Lieutenant Governor automatically succeeds to a gubernatorial opening created by recall, how a successor candidate should qualify for the ballot if there is no automatic lieutenant gubernatorial succession, and what the role of the so-called Commission on the Governorship plays in recall matters. As California Chief Justice Ron George observed, there is much work to be done by the California Legislature, the California Constitution Revision Commission, and the California Law Revision Commission to clear up the confusion. ${ }^{31}$

8.

\section{In Constitutional Litigation, the Standard of Review Is Often Crucial and Is Sometimes Abused.}

As a teacher and scholar in both constitutional law and civil procedure, I love when the two intersect. The recall litigation demonstrates how important the procedural rules under which courts operate are in determining the "real world" content of constitutional constraints. In particular, the "standard of review"- - a procedural device that a court uses in reviewing the actions of another governmental body-is often quite crucial. The standard of review, in essence, frames the question a court asks. And as is often the case, in the recall affair the way the questions got asked went a long way toward determining the answers given.

Consider the two most important cases in which challengers to the recall scheme were able to get at least some judges to take their side. First was the California Supreme Court case of Burton $v$. Shelley, ${ }^{32}$ challenging California Secretary of State Kevin Shelley's decision to borrow from state primary election statutes when deciding how successor candidates could qualify for the second part of the recall ballot. Although the California high court rejected this challenge by dismissing the request for preliminary relief, two justices-Chief Justice George and Justice Carlos Morenodissented, arguing that the claim was perhaps meritorious.

Second was the infamous punch-card challenge based on Bush $v$. Gore, litigated in the Ninth Circuit, where a three-judge panel originally embraced the American Civil Liberties Union (ACLU) plaintiffs' claim

30. Conversations with Jeffrey Bleich, Partner, Munger, Tolles \& Olson (Aug. 2003) (discussing various additional lawsuits plaintiffs and law firms were considering).

31. Burton v. Shelley, 2003 WL 21962000, at *8 (Cal. Aug. 7, 2003) (George, C.J., dissenting).

32. Id. 
that the scheduled October election which would use punch-card machines in some but not all counties would violate the Equal Protection Clause. ${ }^{33}$ Although for eight tense days no one knew whether the election would take place as scheduled or not, an eleven-member en banc panel of the Ninth Circuit ended up unanimously rejecting the three-judge panel's decision and affirming the district court's denial of relief to the ACLU. ${ }^{34}$

In Burton, the California court, in explaining its view that plaintiffs had not demonstrated a likelihood of success on the merits, began by pointing out that " $[t]$ he Secretary of State is the constitutional officer charged with administering California's election laws, and his interpretations of those laws are entitled to substantial judicial deference."35 The court then added that in the present case "deference is especially great ... [because] the Secretary of State conformed to policies consistently followed by his two predecessors, who represented both major political parties." the court again made explicit that the question it was asking was not whether the Secretary erred, but rather whether "there appears . . clear error in the Secretary of State's decision." 37 The court closed its short opinion by observing that there are ambiguities "which require the Secretary of State to exercise his discretion" and that "[i]f the Legislature disagrees with the manner in which the Secretary of State has exercised his discretion, it is within the Legislature's province to specify other procedures." 38

The Ninth Circuit's en banc ruling in the ACLU's punch-card challenge also relied extensively on the notion of deference. In reviewing the district court's denial of the ACLU's request for a preliminary injunction, the en banc per curiam opinion opened by observing that " $[t]$ he standard of review is important to our resolution of this case." 39 The court then stated that "[w]e review the district court's decision to grant or deny a preliminary injunction for abuse of discretion. Our review is limited and deferential." 40 The court did note that a "district court's interpretation of the underlying legal principles ... is subject to de novo review and [that] a district court abuses its discretion when it makes an error of law."41 The court concluded rather easily, though, that under the deferential standard of

33. Southwest Voter Registration Educ. Project v. Shelley, 344 F.3d 882, 900 (9th Cir. 2003), vacated, 344 F.3d 913 (9th Cir. 2003).

34. Southwest Voter Registration Educ. Project v. Shelley, 344 F.3d 914 (9th Cir. 2003) (en banc).

35. Burton, 2003 WL 21962000 , at ${ }^{*} 1$ (citations omitted).

36. Id. (citation omitted).

37. Id. at $* 2$ (emphasis added).

38. Id. at *3. Justice Kennard's concurrence stresses deference as a rationale for the result even more. See id. (Kennard, J., concurring)

39. 344 F.3d at 917.

40. Id. at 918 (citation omitted).

41. Id. 
review, the district court's decision not to grant relief in this case could not be disturbed. ${ }^{42}$

Both of these opinions should remind us that even once a court agrees to consider the merits of a ruling by another actor (be it the Secretary of State or a lower court), the review may ultimately be forgiving. There is a spectrum between a de novo review as a matter of right at one end and a failure to grant review in a case at all (say, in a denial-of-certiorariwithout-comment setting) at the other end. Review with substantial deference can end up being much closer to the latter than to the former.

Indeed, resting a decision on deference to some other body can be such an attractive way for a court to resolve a case that sometimes the deference is itself abused or misapplied. In Burton, for example, the California Supreme Court never really explained why such deference to the Secretary of State is owed in the context of a pure question of law. Do California administrative law principles dictate substantial deference to all executive branch interpretations of law? In the federal system, I am not sure that the so-called Chevron deference idea ${ }^{43}$ applies necessarily to all statutory interpretations by the Federal Election Commission, the entity that oversees federal elections. ${ }^{44}$ Moreover, why should more deference be owed simply because Shelley's position was shared by Republicans who held his office previously? Some interpretations of election law benefit all incumbents, of both parties, and I would not expect deference to follow simply from selfish bipartisan recognition of that fact. In any event, the California Supreme Court should have at least acknowledged, if it was going to rely on policies adopted by Republicans, that such policies never had to be used in a gubernatorial recall before and therefore that no one really knows what would have happened in such a situation under those earlier administrations.

The Ninth Circuit's decision to defer to the district court is also arguably open to question. The plaintiffs, it should be remembered, argued that under Bush v. Gore a state's decision to hold an election where punchcard machines would be used in some counties but not others is inconsistent with the Equal Protection Clause, given that punch-card machines have error rates that are discernibly higher than those associated with better technology such as optical scanning. The district court rejected that broad reading of Bush v. Gore. ${ }^{45}$ The Ninth Circuit en banc panel never really said whether it agreed with the district court's interpretation of law, even

42. Id. at 920 .

43. See Chevron U.S.A. Inc. v. Natural Res. Def. Council, Inc., 467 U.S. 837 (1984).

44. Cf. Colorado Republican Fed. Campaign Comm. v. Fed. Election Comm'n, 518 U.S. 604 (1996).

45. Southwest Voter Registration Educ. Project v. Shelley, 278 F. Supp. 2d 1131, 1140-41 (C.D. Cal. 2003), aff $d, 344$ F.3d 914 (9th Cir. 2003) (en banc). 
though the eleven judges acknowledged that a mistake of law would be an abuse of discretion. ${ }^{46}$

The en banc opinion only came close to saying what it needed to: that the plaintiffs' near absolutist reading of Bush $v$. Gore was wrong as a matter of law and that the district court was legally right to reject it. Quoting Bush v. Gore, the Ninth Circuit observed that " $[\mathrm{t}]$ he question before the Court... [there was] not whether local entities, in the exercise of their expertise, may develop different systems for implementing elections.",47 But the en banc opinion never said that the term "different systems" includes different counting machines. Moreover, the opinion seemed at various points to describe the question not as whether the district court's interpretation of the law was right, but rather whether it was "reasonable" given that the meaning of Bush v. Gore had not been litigated before in the Ninth Circuit. For example, the court said "[t]hat a [three-judge] panel of this court unanimously concluded the [plaintiffs'] claim had merit provides evidence that the argument is one over which reasonable jurists may differ." $" 48$

The proper inquiry is not, of course, whether a reasonable district court could construe Bush v. Gore the way the district court did. The question of whether Bush v. Gore forecloses the use of different kinds of voting machinery across the state when the different kinds of machinery may have significantly different error rates is one of law, and one on which the ACLU had a right to the en banc panel's views. A ruling that the district court's interpretation was reasonable is not the same thing as one saying the district court did not err. As the Supreme Court reminded all of us last term (in a prominent case out of the Ninth Circuit, no less), a "was it objectively unreasonable?" standard is more deferential than, and should not be conflated with, a "was it error?" or even a "was it clear error?" standard. ${ }^{49}$ And the law of preliminary injunction review is straightforward: an error of law-let alone a clear error of law-is an abuse of discretion, even if the error is reasonable. Thus, although the en banc ruling is (perhaps intentionally) vague, I read the Ninth Circuit necessarily as having rejected on the merits the ACLU's legal argument that Bush v. Gore makes any nontrivial intrastate discrepancy in vote counting attributable to the use of punch-card machinery a per se violation of the Constitution. Although relying on a standard of review that counsels deference to the district court may seem an easy way to resolve a tricky case, I am inclined to assume that appellate opinions are respectful of appellants' rights to have their legal theories evaluated on the merits de novo.

\footnotetext{
46. See Southwest Voter Registration Educ. Project, 344 F.3d at 914, 919-20.

47. Id. at 918

48. Id.

49. See Lockyer v. Andrade, 538 U.S. 63, 73-77 (2003)
} 


\section{7. \\ The Political System Can Often Cure Legal Mistakes ON ITS OwN.}

The Burton case serves as a good reminder of how unimportant getting legal rulings right can be at times. On the merits, the California Supreme Court's decision to uphold-even under a deferential standardSecretary of State Shelley's approach regarding access to the successor part of the ballot seems problematic. As a practical matter, many observers worried that if would-be successors needed to surmount only a very low threshold to place their names on the ballot submitted to voters, the number of names appearing on the form could be mind-boggling. This, in turn, could lead to the possibility of voter confusion, and-more importantlyto a scenario in which the ultimate winner received a relatively small percentage of the overall vote, say under $30 \%$, because there was no runoff mechanism in California's recall scheme. ${ }^{50}$ In the end, acceptance of Shelley's position led to a ballot with an amazingly high number of candidates-135.

The California Supreme Court had room, I think, to reject the Secretary of State's position. To begin with, the court could have relied on the history of the recall provisions of the Elections Code. From 1911, when the recall device was first put into place, until 1976, California statutes specifically provided that a person who intended to qualify for the successor part of the ballot needed to collect signatures equal to $1 \%$ of the votes cast at the last election for the office in question. ${ }^{51}$ Such an approach in the 2003 recall would have required each successor candidate to round up about 75,000 signatures (instead of the mere sixty-five signatures that Secretary of State Shelley required). ${ }^{52}$

Second, and perhaps more important, the California Supreme Court could have drawn on a deep tradition in federal case law concerning ballot access requirements. This tradition recognizes the important interest that states have in "keeping [their] ballots within manageable, understandable

50. See, e.g., Editorial, Reform the Recall; Never Fully Tested Before, Change is Needed, SAN Diego Union-Tribune, Oct. 7, 2003, at B6. For a detailed discussion of the merits of the Burton case, see Vikram David Amar \& Alan E. Brownstein, A Mixed Verdict on the California Supreme Court's Decision, Findlaw.com (Aug. 22, 2003), at http://writ.news.findlaw.com/amar/20030822.html. For a discussion of the wisdom of an instant runoff device like single transferable voting in situations like these, see Vikram David Amar, Governor Davis's Claim to Run as His Own Successor Is Meritless, But the Fear of a "Fringe" Winner Is Serious: How the Risk Can Be Eliminated in the Future, Findlaw.com (Aug. 8, 2003), at http://writ.news. findlaw.com/amar/20030808.html.

51. See Burton v. Shelley, 2003 WL 21962000, at *5 (Cal. Aug. 7, 2003) (George, C.J., dissenting) (discussing the requirements prior to 1976).

52. The Secretary of State drew this requirement, and the requirement of a $\$ 3,500$ filing fee, from the provisions in the California Elections Code governing ballot access to party primary elections, even though these provisions by their very terms stated they were not to be used for recall elections. See Cal. Elec. Code $\S \S 8062,8103$ (West 2003). 
limits"-an interest the U.S. Supreme Court has deemed to be of "the highest order." ${ }^{3} \mathrm{I}$ am not arguing here that the U.S. Constitution affirmatively requires states to set their ballot access thresholds higher than did Secretary of State Shelley. Instead, I am suggesting only that the California Supreme Court could have used thc long-recognized interest in ballot manageability to help interpret and make sense of what is an admittedly convoluted and hard-to-decipher ${ }^{54}$ set of state constitutional and statutory provisions. Instead of using this history and principle as a basis for giving a hard look at what the Secretary of State did, the court ignored these things altogether in deferring to Shelley's plan..$^{\text {ss }}$

But any error here by the California Supreme Court turned out to be very harmless indeed. All but three of the major candidates dropped out of the race, and each of the big three-Schwarzenegger, Cruz Bustamantc, and Tom McClintock - could have raised 75,000 signatures in a few weeks if necessary. At the gencral election, all of the other 132 candidates received a combined vote of below $5 \%,{ }^{56}$ an amount not appreciably larger than that received by minor also-rans in a general election preceded by a formal primary process. ${ }^{57}$ In effect, then, the recall election in California turned out to be both a hurried primary election and a hurried general election. For those of us who think courts and legal rulings are all-important, it is good to remember that although rules of law often establish important starting points and baselines, real people and real institutions-like candidates and political parties-often work around rulings and accomplish goals in spite of what courts may do.

53. See Lubin v. Panish, 415 U.S. 709, 715 (1974); Bullock v. Carter, 405 U.S. 134, 144-45 (1972).

54. For example, the 1976 amendments to the Elections Code delete the $1 \%$ signature requirement without any replacement or explanation. See Burton, 2003 WL 21962000, at *5 (George, C.J., dissenting). And the Elections Code contains no other helpful directions to the Secretary of State with regard to successor ballot qualifications for gubernatorial recall elections. Understandably, the Secretary of State and the Califomia Supreme Court didn't want to appear to be "making up" successor requirements. My point is that whatever they did, they were going to be making up the rules here-they might as well have made up rules that made more sense in terms of policy and history.

55. Justice Kennard did mention this issue in her separate concurrence, but then went on to ridicule the idea that there might be "too many candidates on the ballot, giving the People too many choices." Burton v. Shelley, No. S1 17834, 2003 WL 21962000, at *3 (Cal. Aug. 7, 2003) (Kennard, J., concurring) (emphasis omitted).

56. See http://vote2003.ss.ca.gov/Retums/summary.html (Oct. 7, 2003).

57. Indeed, third-party candidates rcceived over $10 \%$ of the vote in the 2002 California gubernatorial election; and Green Party candidate Peter Camejo received a higher percentage of the vote in 2002 than he did in 2003. See California Secretary of State, Statement of Vote: 2002 General Election Nov. 5, 2002 Governor, by County, available at http://www.ss.ca.gov/elections/sov/ 2002_general/gov.pdf (last visited Mar. 17, 2004). 


\section{6.}

\section{In High Profile Constitutional Litigation, Writing an OPINION IS IMPORTANT.}

The Burton case, taken together with the other recall cases before the California Supreme Court, provides another lesson as well, one concerning the importance of well-reasoned judicial opinions.

A statewide recall election is undeniably an extraordinary, and extraordinarily traumatic, political event. It reflects a deep level of distrust of elected public officials by at least a significant percentage of the voting public. And it is precisely at moments like these-when public trust is in doubt - that public officials must act most carefully to avoid the perception that they are abusing power.

This admonition of caution applies not just to executive officers and legislators, but to judges and justices as well. Those who drafted and ratified the recall provisions of California's constitution feared abuses by the judiciary as well as by the other branches. Indeed, the recall device in California was specifically designed to cover judges as well as governors, largely out of a belief that the California Supreme Court had become aligned with corporate interests controlling the state. ${ }^{58}$ Nor was California alone in this regard. As one prominent authority on direct democracy has noted, "[w]ithout a recall power over judges, reformers [in many states] argued, the referendum and initiative [the other components of the progressive agenda] would be 'rendered valueless' by conservative judges seeking to reinstate the status quo." 59

Recent experience illustrates that judges can come in for criticism when they intervene too aggressively. The infamous example of Bush $v$. Gore, of course, involved the U.S. Supreme Court, but the California Supreme Court, like all courts facing election challenges today, must deal with the Bush v. Gore fallout. Moreover, the California Supreme Court itself has been reprimanded by the state's voters in the 1980s for appearing too "activist," especially in the area of capital punishment. Less than two decades ago, the voters of California ousted three sitting Supreme Court Justices-Chief Justice Rose Bird and Justices Joseph Grodin and Cruz Reynoso-in a heated election whose result startled many veteran observers. That experience remains fresh in the minds of California jurists who want to avoid being seen as stepping into political controversies too willingly.

58. See George Edwin Mowry, The California Progressives 140-42 (1951). The argument in support of including judges rested on the idea that judges, like other officials, exercise political power and therefore may act for corrupt and improper reasons. In fact, it was the application of the recall idea to the judiciary that was the most vigorously debated aspect of the recall power in the early 1900s. Id. at 140-50.

59. Julian N. Eule, Judicial Review of Direct Democracy, 99 Y ALE L. J. 1503, 1546 (1990) 
But courts can also come under fire for not interceding when they should. For decades, the federal judiciary has been criticized for using the so-called "political question" doctrine to manipulate its docket and decline to resolve matters-such as the legality of the Vietnam War-that some have argued would have benefited from judicial input. ${ }^{60}$ More recently, and closer to home, defenders of "traditional" notions of marriage and believers in state control over local officials heavily criticized the trial courts in San Francisco for not intervening earlier to enjoin Mayor Gavin Newsom from directing the issuance of same-sex marriage licenses in overt defiance of state statutes he believes to be unconstitutional. ${ }^{61}$

Given the potential for heat either way they go, courts can never completely insulate themselves from accusations of politicization. But courts' best defense here is to engage in a full and fair discussion of the competing arguments and provide a clearly stated explanation of the reasons behind their judgments. Well-reasoned explanations, in the form of judicial opinions, are a key institutional feature that distinguishes the exercise of judicial power from other kinds of government power, and one that will reduce, though not entirely eliminate, suspicions among the polity. In short, judges have a duty to explain to the parties and the world not only what decisions they reach, but also why those decisions have been reached. ${ }^{62}$ And this is where the California Supreme Court probably receives its worst marks.

In resolving all the disputes before it, the California Supreme Court provided a total of five pages of analysis defending the results it reachedfive total pages to dispose of five separate cases. ${ }^{63}$ And those five pages discussed only two of the six substantive claims raised. Such summary explanation, even in a context of difficult time restraints, does little to

60. For a good general discussion of the political question doctrine and criticisms that have been made of various specific cases, see Robert J. Pushaw, Jr., Judicial Review and the Political Question Doctrine: Reviving the Federalist "Rebuttable Presumption" Analysis, 80 N.C. L. REv. 1165 (2002).

61. See, e.g., Arnold: Terminate Same Sex Marriage: Orders Immediate Action by State AG to Stop San Francisco's Illegal Licenses, World NET DaIly (Feb. 21, 2004), at http:/www.worldnetdaily.com/news/article.asp?ARTICLE_lD=37239.

62. As David Shapiro has observed, "reasoned response to rcasoned argument is an essential aspect of [the judicial] process. A requirement that judges give reasons for their decisions-grounds of decision that can be debated, attacked, and defended-serves a vital function in constraining the judiciary's exercise of power." David L. Shapiro, In Defense of Judicial Candor, 100 HARV. L. REv. 731,737 (1987). For this reason, the California court praetiee of "depublishing" opinions, like the practice in some federal courts of writing unpublished opinions that no parties may cite, is the subject of mueh recent controversy. See generally Stephen R. Barnett, Depublication Deflating: The California Supreme Court's Wonderful Law-Making Machine Begins to Self-Destruct, 45 HasTings L. J. 519 (1994).

63. See Robins v. Shelley, No. S117661, 2003 Cal. LEX1S 5661 (Cal. Aug. 7, 2003); Eisenberg v. Shelley, No. S117763, 2003 Cal. LEXIS 6099 (Cal. Aug. 7, 2003); Burton v. Shelley, No. S117834, 2003 WL 21962000 (Cal. Aug. 7, 2003); Davis v. Shelley, No. S117921, 2003 Cal. LEXIS 6103 (Cal. Aug. 7, 2003); Frankel v. Shelley, No. S1 17770, 2003 WL 21961996 (Cal. Aug. 7, 2003). 
reassure a nervous public that the court is neither usurping nor abdicating authority.

The California Supreme Court's failure to fully explain itself is perhaps most troubling with respect to the very justiciability of the lawsuits themselves, an issue the Justices ignored altogether. Incredibly, the court never explained why it had jurisdiction over the two cases it decided on the merits, even after the defendants in these two matters raised serious challenges to plaintiffs' standing to file suit in the California Supreme Court. Defendants contended that the exclusive power to sue rested in a particular government agency, the so-called California Commission on the Governorship, and this argument seemed quite forceful.

The California constitution, in Article V, section I0, specifies that " $[t]$ he Lieutenant Governor shall become Governor when a vacancy occurs in the office of Governor" and then goes on to provide that "[ $t$ ]he Supreme Court has exclusive jurisdiction to determine all questions arising under this section" and that "[s]tanding to raise questions of vacancy or temporary disability is vested exclusively in a body provided by statute." 64 The California legislature, implementing this constitutional provision, has passed Government Code section 1207I, which establishes the California Commission on the Governorship and gives the Commission exclusive authority to pursue judicial redress to "determine any questions that arise relating to vacancies in and succession to the office of Governor." 65

Both lawsuits in which the California Supreme Court spoke on the merits were filed by private parties, rather than the California Commission on the Governorship, and thus were arguably barred by these provisions. Surely, the action-Frankel $v$. Shelley-brought to establish that the Lieutenant Governor should automatically become Governor in the event of a recall was one that only the Commission may bring, under the terms of the constitution, since it turned on whether a recall creates a "vacancy" within the meaning of Article V, section 10. Burton v. Shelley, the other lawsuit on which the high court opined, concerning the qualifications for successor candidates to get on the ballot, arguably involved a "question[] that arise[s] relating to ... succession to the office of Governor" such that standing would be barred by the statute. ${ }^{66}$ At a minimum, the court owed an explanation of why these constitutional and statutory provisions do not mean what they seem to say.

64. CAL. CONST. art. V, $\S 10$ (amended 1974).

65. CAL. Gov't. CoDE $\S 12071$ (West 1992).

66. See id. Note that the statute may be broader than the state constitution in the exclusive powers it gives to the Commission (to deal with matters of "succession" as well as "vacancy"), but so long as there is no independent state or federal constitutional flaw in the statute, it should be respected and obeyed by state courts, including the California Supreme Court. 
5.

The Structure Underlying the Federal Constitution Differs Greatly From That Which animates State Constitutions.

The California Supreme Court's casual treatment of justiciability doctrines, a set of constitutional constraints with which federal courts seem obsessed as a matter of separation of powers, is just one illustration of how different the structural relationships between various institutions are under the federal Constitution as compared to those of the several states. Consider first the relationship between the people and their elected representatives. Since their inception after the Revolution, state constitutions have been premised on the understanding that elected leaders "be in miniature an exact portrait of the people at large. [They] should think, feel, reason and act like them." 67 The relationship between elected representatives and the voters who picked them was often described in the earliest state constitutions in master/servant terms. The original Pennsylvania constitution of 1776 was fairly typical in this regard when it observed in one of its first provisions that "all power being originally inherent in, and consequently derived from, the people; therefore all officers of government, whether legislative or executive, are their trustees and servants, and at all times accountable to them."68 Moreover, "[v]oters in most states also had the right to instruct their [legislative] representatives and to direct votes on individual issues.... [Three original] state constitutions [explicitly] guaranteed such a right. In the others, the right was assumed." 69 As the eminent Gordon S. Wood has explained, during the period between the Revolution and the framing of the Constitution, "many Americans believed their representatives to be ... mere agents or tools of the people who could give [them] binding directions." 70

Because of this direct agency relationship, the people of most states provided for frequent elections of both legislative and executive officials. Elections for the lower house of the state legislature were originally held each year in every state but one; most states also placed the maximum term of office for the chief executive at just one year; and two states forbade executive reelection. ${ }^{71}$ Although by the time the federal Constitution was adopted some states had loosened controls over state legislative and

67. John Adams, Thoughts on Government (1776), reprinted in 1 American Political Writing During the Founding ErA, 1760-1805, at 403 (Charles S. Hyneman \& Donald S. Lutz eds., 1983).

68. Pa. Const. $\$ 4$ (1776), reprinted in 5 Thorpe, The federal and State Constitutions, Colonial Charters, and Other Organic laws 3082 (1909).

69. Daniel A. Farber \& Suzanna Sherry, A History of the American Constitution 111 (1990); see also Amar, supra note 15, at 1047-53. Instruction of governors was not a topic that arose, in large part because governors were often controlled and elected by legislatures, who were in turn subject to instruction.

70. Gordon S. Wood, The Creation of the American Republic, 1776-1787, at 371 (1969).

71. FARBer \& SHERRY, supra note 69 , at $79-81,110$. 
executive officials and given them more delegated power, the backdrop in 1787-against which the power of formal recall inserted into the California constitution in the early twentieth century must be viewed-was one in which the people of each state formally retained power to control their elected representatives, to whom the people had given relatively short leashes.

Unlike state practice, recall and the related right to formally bind elected representatives with instructions were never thought to be parts of the federal constitutional structure. Under the Articles of Confederation, the delegates to the national Congress, selected by the state legislatures, were recallable by the states. ${ }^{72}$ The Framers of the Constitution explicitly rejected this approach in order to give federal legislators more independence from the states where they resided. We can see this particularly clearly when we consider a proposal made during congressional deliberation over what ultimately became the First Amendment. Various of the state conventions that had ratified the Constitution did so by appending declarations of rights to the ratification - constitutional "wish lists" for possible amendments to the new document. Many of these declarations contained a "right to instruct." voted down proposed language recognizing a right to instruct federal legislators, and the Bill of Rights package that was sent by Congress to the states made no mention of "instruction."

The reasons provided for rejecting the "instruetion" of members of Congress were quite forceful. Congresspersons, unlike state officials, are required by the Constitution to "assemble" and hold "meetings" with House members and Senators who are "inhabitants of" the other states from which they were selected, and then deliberate to determine what is in the national good. Even though federal legislators are selected from different states so that each region's desires, values, interests, and information are represented in the national dialogue, strictly speaking federal legislators are beholden to the country, and not just the state from whence they came. As Founding Father Roger Sherman of Connecticut put it, binding federal legislators to instructions "would destroy the object of their meeting. I think when the people have chosen a representative, it is his duty to meet others from the different parts of the Union, and consult, and agree with them to such acts as are for the general benefit of the whole community.",74

72. ARTICles OF CONFEDERATION art. V, para. 1 (U.S. 1781).

73. See Akhil Reed Amar, Philadelphia Revisited: Amending the Constitution Outside Article V, 55 U. CHI. L. REV. 1043, 1059 (1988).

74. 1 ANNALS of CoNG. 763 (Joseph Gales ed., 1834). For a detailed discussion of federal legislative instruction, see Amar, supra note 15, at 1049-53. Instruction of the President never came up at the founding, because the President wasn't (and still isn't) elected by a permanent body like the people of each state (who elect the House of Representatives and the Senate) or the legislature of each state (who, before the Seventeenth Amendment, elected the Senate). Instead, the President is elected by 
There is no similar requirement of intrastate deliberation for state government; a state could, consistent with the federal Constitution, select all its legislative leaders through an at-large system and allow its state legislators to vote on legislation without ever meeting to deliberate. In short, state government can be, and often is, much more directly "people-driven."

Nor is the relationship between the people and their representatives the only big structural difference between the federal and state constitutions illustrated by the recall. Consider also the relationship between the executive branch and the legislative branch in the context of filling executive vacancies. The federal Constitution imposes limits on whom Congress may place in the line of succession after the President and Vice President. The Constitution's so-called "Succession Clause" limits succession to "officers," 75 a term best read to exclude legislators from the line of presidential succession. ${ }^{76}$ Indeed, the so-called "Incompatibility Clause" makes clear that House and Senate members should not be considered "officers" because federal legislators are prohibited from "holding any office under the United States." 77 Instead, apostolic succession-succession by those people in the President's cabinet-is preferred.

By contrast, state gubernatorial succession is more complicated. State constitutional incompatibility clauses can be quite different from the federal version. For instance, the Incompatibility Clause in the California constitution does not disable a legislator from holding executive or judicial office, but rather precludes legislators only from offices that are nonelective ${ }^{78}$ Moreover, the California constitution's Succession Clause does not limit the legislature to picking "officers" who may ascend to the Governorship, but rather says simply that " $[\mathrm{t}]$ he Legislature shall provide an order of precedence after the Lieutenant Governor." 79

a group of "electors" (a body that today we call the "electoral college") whose powers and duties end after they cast their presidential ballots. See U.S. CONST. art Il, $\S 1$.

75. U.S. CONST. art. 11, § 1, cl. 6.

76. See Akhil Reed Amar \& Vikram David Amar, Is the Presidential Succession Law Constitutional?, 48 STAN. L. REv. 113, 114 (1995). Although the federal succession statute currently in the U.S. Code purports to place legislators (the Speaker of the House and the President Pro Tempore of the Senate) in the line of presidential succession, this was not true for most of American history, and many (most?) leading constitutional scholars think the current statute is at least constitutionally problematic. See, e.g., Steven G. Calabresi, The Political Question of Presidential Succession, 48 STAN. L. REv. 155 (1995). Due in large part to these constitutional concerns voiced by the academy, Congresspeople from both parties are right now engaged in a statutory amendment process that 1 hope will cure the problem. For a look at the ongoing legislative deliberations, see the proceedings of the joint hearing of The Senate Committee on the Judiciary and the Senate Committee on Rules and Administration, entitled "Ensuring the Continuity of the United States Government: The Presidency," Sept. 16, 2003, available on the Senate Judiciary Committee's website, http://judiciary.senate.gov/ hearing.cfm?id=914 (last visited Feb. 5, 2004).

77. U.S. Const. art. $1, \S 6, \mathrm{cl} .2$.

78. CAL. Const. art. IV, $\$ 13$.

79. Id. art. $\mathrm{V}, \S 10$. These differences are to be somewhat expected. The federal lncompatibility Clause and the limitation of succession to "officers," like the adoption of the "eleetoral college" mode 
The odd office of the Lieutenant Governor in California itself illustrates the complexity of state constitutions. In California, if a gubernatorial vacancy is created by impeachment, resignation, death, or disability, the Lieutenant Governor, who is elected independently of the Governor, assumes the Governor's office. ${ }^{80}$ But-and this was the focus of one of the lawsuits filed - if the opening comes about through a recall, then a new instant replacement election is held. ${ }^{81}$ It is not at all clear why California fills gubernatorial vacancy differently depending upon how the vacancy is created. In some ways, recall can be easily likened to impeachment. Indeed, recall, like the initiative and referendum, was a Progressive response to the fear of legislative capture or inertia. In other words, the recall-like the initiative and referendum-gives the people the power to do what the legislature should be doing (i.e., impeaching) but is not. But if a recall is the "people's impeachment," then why not have lieutenant gubernatorial succession for recall as you would for impeachment? ${ }^{82}$ This is one of the questions to be explored in the reform debate.

\section{4. \\ Resorting to the People May Cure Constitutional Defects, Sometimes.}

Before 2003, most people knowledgeable about the California recall device would have thought that recalls are reserved for a few specific situations. First, recall is obviously appropriate when an elected or appointed

of electing Presidents, reflects the Framers' rejection of a parliamentarian model where the chief executive is selected by the legislature and owes his job to it. State executive independence from state legislatures is a much newer phenomenon. Although today governors are elected by the people directly, most early state constitutions gave the state legislature the power to select the Governor. State constitutional provisions like California's Succession Clause are vestiges of an early state constitutional approach that never characterized the federal Constitution.

80. See id.

81. The California constitutional recall provisions added to the document in 1911 clearly provided for a successor election in the event of a gubernatorial recall. The California constitution was amended again in 1975, and the words "if appropriate" were inserted to describe when a successor election was to be held after successful recalls. If one were construing only the words and structure of the post-1975 constitution, one might easily conclude that the words "if appropriate" foreclosc a successor election for those offices, like the Governor, that already have a succession procedure spelled out clsewhere in the constitution. But if one interprets the post-1975 constitutional text and structure against the backdrop of the 1911 version, and with the intent of those who amended the document in 1975 in mind, one should conclude, as did the California Supreme Court in Frankel v. Shelley, No. S117770, 2003 WL 21961996, at*1 (Cal. Aug. 7, 2003), that the words "if appropriate" are designed only to help eliminate successor elections for certain judicial vacancies created by recall. These judicial vacancies created by recall were the focus of the 1975 amendment efforts and were dealt with in other 1975 textual amendments that overlap with the newly added words, "if appropriate."

82. For examplc, there is no obvious reason to think that the explanation for a governor's unpopularity in a recall setting necessarily carries over and applies to a lieutenant governor, any more than would the explanation for a gubernatorial impeachment. 
official has become corrupted by corporate or other special interests such that she no longer acts in the public interest. That, after all, was the primary explanation advanced by California Progressives in the early 1900s concerning the need for a recall device. ${ }^{83}$ Second, and related, recall seems the proper remedy when an official has gone back on key promises she made to the people about her public agenda in order to secure election or appointment. ${ }^{84}$ Under such circumstances, the people should be able to make use of the recall process to undo a selection process in which they were effectively sold a false bill of public goods. Taken together, these two scenarios-corruption and election deception-describe the early invocations of the recall instrument by the people in California. ${ }^{85}$

By contrast, there is no evidence to suggest that framers, adopters, and early users of the recall measure saw it as a mechanism to rerun an ordinary election in which there had been no dishonesty and after which there had been no evidence of special interest group capture. To be sure, the limited circumstances for which recall was appropriate were not explicitly written down in the state constitution, in the same way, say, that impeachment in the California constitution is reserved for "misconduct in office" crat can administer it. The California constitution nowhere overtly says what a good reason for a recall is and indeed explicitly prohibits the Secretary of State from refusing to certify signatures because the reason for recall is insufficient. ${ }^{87}$

Nevertheless, here, as elsewhere, text does not resolve the matter entirely, for text (or lack thereof) is just one methodological tool used to interpret constitutions. Californians may well have had clear expectations and understandings that recalls would be limited to certain extraordinary kinds of situations, even if they wanted to make clear in the constitution that an elected official (or even a judge) would have no ability to secondguess the reasons citizens may advance. And these historical understandings, as well as the larger constitutional structure of which the recall provisions are a part and the subsequent history implementing the expectations of the ratifiers, help us decide what a constitution means and what limits it places on day-to-day activity.

One reason many people were critical of the Davis recall movement is that it did not fit this historical paradigm very well. Some Davis recall proponents did argue early on that he had misled voters in 2002, when he was up for reelection, about the size of the state budget deficit and should be

\footnotetext{
83. See generally Garrett, supra note 19.

84. Id.

85. Id.

86. CAL. Const. art. IV, § I8(b).

87. See id. art. II, § I4(a).
} 
punished for his deception. ${ }^{88}$ But he did not really mislead voters any more than all the legislators who ran in 2002 , or more than other governors had in many other elections held at times when the economy was slipping into deep recession. That is why, when the recall campaign kicked into high gear, the "lies about the budget" argument receded into the background, and the more general critique of Davis's character and effectiveness-a critique that had been made by his opponents in prior elections as welltook center stage.

This explains fairly well why so few voters who had supported Davis in 2002 voted in favor of his recall less than a year later. Last October, around $45 \%$ of the electorate voted against the recall-that is, voted in favor of keeping Davis in office. ${ }^{89}$ That may seem low, especially for an incumbent. But bear in mind that in November of 2002, incumbent Davis was reelected with only $48 \%$ of the vote. ${ }^{90}$ In other words, in 2002 he lost $52 \%$ of the vote; in 2003 , he lost $55 \%$.

Nor was the 2003 voting behavior much more bipartisan than that seen in 2002. Much has been made of the fact that Davis lost over $20 \%$ of Democrats on Part One of the recall ballot. ${ }^{91}$ Yet that means almost $80 \%$ of Democrats voted against the recall. By contrast, almost $90 \%$ of Republicans favored it. ${ }^{92}$ In short, people largely voted on Davis in 2003 the same way they did in 2002 . The different outcomes in the two years, of course, stem from the fact that in 2003 Davis needed, by virtue of the recall rules, $50 \%$ to win, whereas a year earlier there was no such requirement and Davis was able, in fact, to eke out a victory with less than $50 \% .^{93}$ It

88. An early pro-recall website, posted by the "California Republican Assembly (CRA)," illustrates this. In March/April 2003, the CRA urged support for the recall on the ground that "as he campaigned for re-election, Davis lied about the size and scope of the budget crisis facing California." Recall Gray Davis, 33 Cal. RepubliCan (Mar./Apr. 2003), at http:/www.ca-republican.com/ $3310 / 3310 \mathrm{~b} . \mathrm{htm}$. Interestingly, in a move that foreshadowed the thrust of the recall campaign in the fall, the website then goes on to argue for the recall on the ground that "from the outset of his administration, Gray Davis has failed the leadership test." Id.

89. See http://vote2003.ss.ca.gov/Returns/summary.html (Oct. 7, 2003).

90. See Califomia Secretary of State, Statement of Vote: 2002 General Election Nov. 5, 2002 Governor, by County, available at http://www.ss.ca.gov/elections/sov/2002_general/gov.pdf (last visited Mar. 17, 2004),

91. See CNN.com, Special Report, Exit Polls: Special Election, at http://www.cnn.com/ ELECTION/2003/recall/pages/epolls/special.election.html (last updated Mar. 18, 2004).

92. Id.

93. In one lawsuit before the California Supreme Court, Davis did argue that federal constitutional principles - in particular his equal protection rights and those of his backers-gave him a right to compete on the second part of the recall ballot alongside other candidates and win should he obtain the most votes, regardless of whether he rcached 50\%. See Martin Kasindorp, Lawsuits: Recall Wrongs Davis, Voters, USA TODAY, Aug. 5, 2003, at 3A. This argument, while intuitively attractive, was seriously flawed. The simple if harsh reality is that states frequently exclude persons who might in fact be the most popular candidates from running, through devices such as term limits, age thresholds, and residency requircments. These ballot access limitations can easily (especially in the case of term limits) prevent the persons who could garner the most votes from competing at all. And yet, as long as these candidacy hurdles are nonpartisan and reasonable, courts routinely uphold them. Here, 
also appears that Schwarzenegger was a more appealing rival than was Bill Simon (Davis's 2002 Republican opponent), perhaps leading some independents to vote against Davis on the first part of the ballot. In the end, though, Davis was recalled because he was not a popular leader, principally because the voters held him responsible for failures-both policy and personal-that predated his reelection in November $2002 .{ }^{94}$ He likely would have been booted in the 2002 contest had voters felt that there were an attractive or even acceptable alternative at that time.

But if the Davis recall election did not fit neatly into the preexisting categories of recall elections, and instead amounted to a "do-over" election to oust an unpopular governor who had not been dishonest and who had not become corrupt, it remains to ask whether such a rerun is a constitutionally legitimate exercise. At one level, the answer is clearly yes, insofar as the people of California have an absolute right, through peaceful majoritarian processes, to "alter and abolish" their form of government-which includes the right to add new categories of permissible recalls-assuming their changes do not violate the federal Constitution.

The theory of popular sovereignty-the foundation upon which the entire edifice of American constitutionalism is built-means that Californians can change their rules, including their recall rules, anytime they want, so long as the new rules are themselves amenable to change by a majority at a later time. ${ }^{95}$ In making clear that nothing in the federal

California's telling someone who was so contentious that he just got recalled from the state's highest and most visible office that he now has to sit on the sideline (at least until the next election), presumably so that the state can more easily get beyond whatever crisis triggered the recall, seems reasonable enough. Indeed, I think California's interest here is stronger than those that have been relied upon, in both state and federal courts, to uphold California's lifetime legislative term limits.

Moreover, while it is true that Davis was being treated differently-unequally-in that he alone was excluded from the second part of the ballot, all others (including Schwarzenegger) were excluded from the first part. (Davis could have won the first part, and retained office, with $50 \%$ of the vote, even if $67 \%$ preferred Schwarzencgger to him.) Because each of the two parts of the ballot effectively involved a distinct question, equality principles were not offended when each part was governed by a different set of rules.

Having said that, though, 1 shouId add that given the way the media styled this election as simply a regular competition between Davis and his competitors-with no real differentiation between the two parts of the ballot-Davis's claim to be on the second part of the ballot, while legally a loser, has some moral appeal.

94. This intuition was confirmed by the internal tracking poll data discussed by many campaign strategists, including Davis's important advisor, Garry South, at an October I8, 2003 postmortem election conference held at U.C. Berkeley and cosponsored by the Institute of Govemmental Studies (IGS) at Berkeley. Summarics or transcripts of the proceedings are available on the IGS website, http://www.igs.berkeley.edu.

95. Analogously, when the federal Constitution proposed for ratification was attacked on the ground that it was changing the rules that had been laid down earlier in each state constitution and was thus "illegal," Federalist defenders responded along the following lines: "The people were in fact, the fountain of all power, and by resorting to them, all difficulties were got over. They could alter constitutions as they pleased." 2 The ReCords of the Federal. Convention of 1787, at 476 (Max Farrand ed., 1937) (statement of Madison). 
Constitution-including the Guarantee Clause-interferes with this general power of state self-determination, Alexander Hamilton reminded everyone in The Federalist that the Clause "could be no impediment to reforms of the State constitutions by a majority of the people in a legal and peaceable mode. This right would remain undiminished."${ }^{.96}$

But the popular sovereignty right of people to abolish and alter their forms of government does not mean that people of a state can do anything they want, any way they want, at any time they want: "Majority rule popular sovereignty presupposes a deliberate majority of the collective 'people,' not a mere mathematical concatenation of atomized 'persons." "997 That is one reason why Article V's procedures for federal constitutional change are quite cumbersome and time-consuming. That is also why, when the federal Constitution was originally adopted, special "conventions"groups of people selected specifically for the sole task of considering the Constitution's new set of ground rules-were used. The very idea of "conventions" represented moments of high, rather than ordinary, politics. As one enthusiastic intellectual defender of popular sovereignty has put the point, majority rule is not the same as majority will and certainly not the same as majority whim. ${ }^{98}$

In California, we have set out in our own constitution a means for the people to make amendments altering our form of state government directly. The same Progressive era that brought us the recall also introduced the initiative process, whereby Californians can enact statutes or make constitutional changes merely by gathering signatures to place a measure on the ballot and then approving it by a simple majority vote. ${ }^{99}$ California's process for changing its constitutional ground rules is much less onerous than the federal process or that used in many other states. ${ }^{100}$

96. The Federalist No. 21, at 136 (Alexander Hamilton) (Clinton Rossiter ed., 1961).

97. Akhil Reed Amar, The Consent of the Governed: Constitutional Amendment Outside Article $V, 94$ Colum. L. Rev, 457, 502 (1994).

98. See id. at 501-04.

99. The signature requirements are $5 \%$ of the number of people who voted in the last gubernatorial election for an initiative statute and $8 \%$ for a initiative constitutional amendment. CAL. CONST. art. 11, $\S 8($ a). A simple majority of voters is all that is needed to enact either. CAL. ConST. art. Il, § 10(a). State constitutional amendments are thus not much more difficult to accomplish than initiative statutes. Initiative statutes are akin to constitutional amendments in another respect, too. Like a constitutional amendment, an initiative statute may not be undone by the legislature (unless the initiative statute explicitly so provides). CAL. CoNST. art. II, § II(c). The similarities, and differences, between state initiative statutes and initiative constitutional amendments become important when one decides whether a voter-approved initiative violates the state constitution. See Eule, supra note 59, at $1545-48$.

100. For example, the state constitutional amendment process underway in Massachusetts on the subject of same-sex marriage features a series of proposed enactments by the legislature, spaced out over two legislative sessions, and then submitted to the state's voters a year later. See, e.g., The Process of Amending the Massachusetts Constitution, Boston.com News (Mar. I2, 2004), at http://www.boston.com/news/local/massachusetts/articles/2004/03/12/the_process_of_amending_the_ massachusetts_constitution/. 
But the fact that in California we have made it relatively easy to amend our constitution does not mean we should change our recall ground rules without consciously doing so. Perhaps there were good arguments in California for expanding the categories of permissible recalls in the Davis case. Maybe, for example, a "do-over" category for gubernatorial recalls makes sense where, as here, the subject of the recall unduly influenced the choices put before the voters at the last election by interfering in the other party's primary election process. ${ }^{101}$ A narrowly defined addition such as this, focused on campaign misdeeds, would have the virtue of not encouraging so-called "sore loser" recall campaigns that many political scientists have argued could be harmful to the long-term stability of government. ${ }^{102}$

We will never know if these arguments could have won the day. For, regrettably, we Californians never had a deliberative dialogue over the contours of and the long-term consequences created by new categories for recalls. ${ }^{103}$ We never engaged in a sustained public discussion of what kinds of reasons ought to justify a gubernatorial recall and whether Davis's case in 2003 presented any such reasons-even though those were the very questions ostensibly presented by Part Onc on the recall ballot. Some of the blame for this must lie with the California press, which covered the campaigu as if the only issue were which of the four major candidates would make for the best governor. ${ }^{104}$ But more of the blame rests with "we the people" ourselves. If we are going to change constitutional rules-as we surely have the power to do-the lesson to learn for the future health of our political system is that we should do so consciously, carefully, and deliberately.

3.

The Fundamental Governmental Power to Hold Elections at Scheduled Times Limits the Fundamental Right to Vote.

Much attention throughout the recall process was paid to the fundamental right to vote and the associated right to have one's vote counted on

101. Davis interfered by spending millions of dollars attacking Richard Riordan during the Republican primary campaign, in the hope that Riordan would lose to Simon, whom Davis considcred a less dangerous opponent in the general election. While such across-party primary meddling is not illcgal or unprecedented-it was used by Richard Nixon against the Democrats in 1972-it is sleazy and calls into question the legitimacy of the outcome. Nixon's win in 1972 was tainted by many illegitimate election tricks, some of which were, of course, illegal. $C f$. Jonathan Chait, Push Up, NEw RePUblic ONLINE (Oct. 10, 2003) available at http://www.perkowitz.net/journal/involve/ tnr-031010-dean.html (analyzing the practice as applied to President George W. Bush in 2004).

102. See, e.g., Bruce E. Cain, The State's Recall Laws Clearly Could Use a Little Tweaking, L.A. Times, Aug. 17, 2003, at M5.

103. For commentary on this problem, see, for example, Stanford University Communications Professor Shanto lyengar's remarks on KQED FM's Forum Program, Oct. 6, 2003, available at http://www.kqed.org/programs/program-archive.jsp?proglD=RD19\&ResultStart=171\&ResultCount= 10\&type=radio.

104. See id. 
equal terms with others. That was, after all, the basis on which a threejudge panel of the Ninth Circuit-for eight days at least-effectively placed the October election on hold. What the three judges forgot, however, is that there is a fundamental interest on the other side of the legal equation: the government's need to hold elections at the appointed times. The three-judge panel completely dismissed the state's argument that replacing the allegedly problematic punch-card machines with newer technology would compromise the state's goal of holding the election in October as planned. Remarkably, the court held that California's preference for an October 2003 election rather than a March 2004 election (presumably the earliest time the new technology could be implemented) was constitutionally "arbitrary," so that any minimal burden, no matter how small, on the voters' ability to have their votes counted in an October election was unconstitutional under the so-called rationality review test. ${ }^{105}$ According to the panel, the difference between the two dates was trivial since under state law the election would have been held in March had the signatures triggering the recall been certified a few months later than they were. ${ }^{106}$ The failure to recognize the importance of adhering to stateprescribed timelines for elections was perhaps the most inflammatory of the three-judge panel's analytic moves.

The en banc panel that came out the other way certainly recognized the importance of holding elections when planned. Indeed, the en banc court cited cases that stand for the proposition that delaying an election is an extraordinary remedy that should be avoided even when there likely would be constitutional violations if the election were held as scheduled. ${ }^{107}$ Unfortunately, these earlier cases do not quite explain why this is so.

I think the answer is similar to the reasons why the right to vote itself is so sacred. As the Court observed in Yick Wo v. Hopkins ${ }^{108}$ and then amplified in the landmark case of Harper $v$. Virginia State Board of Elections: ${ }^{109}$

[the] 'political franchise of voting' ... [is] a 'fundamental political right because [it is] preservative of all rights'... . [Because] the right to exercise the franchise in a free and unimpaired manner is preservative of other basic civil and political rights, any alleged

105. Southwest Voter Registration Educ. Project v. Shelley, 344 F.3d 882, 900 (9th Cir. 2003), vacated, 344 F.3d 913 (9th Cir. 2003).

106. Id.

107. See Southwest Voter Registration Educ. Project v. Shelley, 344 F.3d 914, 918 (9th Cir. 2003) (en banc) (citing Ely v. Klahr, 403 U.S. 108, 113, 115 (1971); Whitcomb v. Chavis, 396 U.S. 1055 (1970); Kilgarlin v. Hill, 386 U.S. 120, 121 (1967)).

108. 118 U.S. 356,370 (1886).

109. 383 U.S. 663 (1966). 
infringement of the right to vote must be carefully and meticulously scrutinized.'110

The right to vote determines the meaning of, and the limitations on, all of the other rights an individual enjoys; it is the most foundational of all rights. But balanced against this right is the equally foundational right of majorities to make law. This right is dependent upon the legitimacy that comes from elections held when scheduled. Thus, the government's ability to hold elections as planned is equally "preservative" of all other government powers.

None of this is to say that the government's need to hold elections as scheduled always outweighs the interests of individuals or groups in making sure that the elections are held on fair and equal terms. ${ }^{111}$ Instead, it is to say only that the constitutional law of elections is complicated because we care deeply not just about getting something done right, but also about getting it done on schedule, so that other things can get done as well.

2.

\section{The Ever-Criticized Ninth Circuit Deserves Some Credit, and a Little Blame, for Its Treatment of Difficult Constitutional Litigation.}

Now that we have put the Ninth Circuit proceedings back on the table, let us evaluate them. We do so against a backdrop of national skepticism about the westernmost circuit. Indeed, it is commonly accepted these days that the Ninth Circuit is the most watched, and most criticized, of all the lower federal courts in the country.

I have eIsewhere explained in some detail my views about the fairness of this criticism. ${ }^{112}$ It is true that the Ninth Circuit has been reversed by the Supreme Court more often than have other courts of appeal over the last decade or so. More importantly, the Ninth Circuit tends to be reversed lopsidedly or unanimously by the Court somewhat regularly, so that if one asks how many "votes" per case the Ninth Circuit attracts in each of its cases that are reviewed by the Court, the Ninth Circuit's average is lower

110. Id. at 667 (quoting 118 U.S. at 370; Reynold v. Sims, 377 U.S. 533, 561-62 (1964)).

111. Indeed, 1 think current law places would-be plaintiffs in a bit of a bind. They have a tough time demonstrating a sufficient likelihood of a non-harmless violation of their right to have their vote counted to make their case ripe for adjudication. And if the case is not ripe and the margin of victory turns out to be substantial, there is no after-the-fact remedy. One has to wonder whether there really is a right to have one's vote counted on equal terms with other people, apart from a right to have one's chosen candidate prevail if she gets the most votes. See generally Vikram David Amar \& Alan Brownstein, The Hybrid Nature of Political Rights, 50 STAN. L. REv. 915 (1998).

112. See Akhil Reed Amar \& Vikram David Amar, Does the Supreme Court Hate the Ninth Circuit? A Dialogue On Why That Appeals Court Fares So Poorly, Findlaw.com (Apr. 19, 2002), at http://writ.news.findlaw.com/amar/20020419.html; see also Vikram Amar, A Chance to Judge the Judges, SAN Jose Mercury News, Sept. 28, 2003, at 1P; Vikram David Amar, The Ninth Circuit May Stand Unjustly Accused, L.A. TIMES, Sept. 11, 2003, at B17. 
than that of the other circuits. I have written about some possible explanations for these phenomena, including the special attention the Supreme Court pays to the Ninth Circuit, as well as the ideological makeup of the Circuit's active judges, as measured by the political party of the Presidents who appointed them. ${ }^{113}$

Here is another part of the explanation: oftentimes when the Supreme Court reverses the Ninth Circuit, the Circuit is guilty not of directly disobeying past directives issued by the Court, but rather of failing to anticipate future moves that most knowledgeable observers expect the high Court to make. Indeed, quite often, as in the "one nation under God" case, ${ }^{1 / 4}$ various recent challenges regarding the scope of Congressional authority under the Commerce Clause, ${ }^{115}$ and the three-judge panel's decision in the recall case, the Circuit uses the Court's own words to arrive at destinations the Court would likely not reach. ${ }^{116}$ But there is a difference between a refusal to follow and a disinclination to take the lead in the direction you expect the Supreme Court to go, notwithstanding the language in its earlier opinions.

One recurring complaint against the Circuit is that it disregards majoritarian interests and instead obsesses over individual and minority group rights. Yet that certainly cannot be said of the unanimous thirteen-page en banc ruling in the recall case issued by the eleven-judge panel whose judges were appointed by four different Presidents, two Democrat and two Republican. The panel held that concerns for individual rights, while "legitimate," could not trump the reliance interests of the participants and voters who had been planning for weeks around the October 7 election date. As the en banc court wrote, we simply cannot ignore the "investments of time, money, and the exercise of citizenship rights" by the "[h] undreds of thousands of absentee voters [who] have already cast their votes."117

Many Ninth Circuit detractors also assert that its size and the physical impracticability of bringing twenty-six judges together for a true en banc panel to hear the most controversial matters breeds an intra-circuit independence that leads three-judge panels to go their own ways. Indeed, those

113. See sources cited supra note $\mathbf{1 1 2 .}$

114. Newdow v. United States Congress, 292 F.3d 597 (9th Cir. 2002), cert. denied sub nom. United States v. Newdow, 124 S. Ct. 383 (Oct. 14, 2003), cert. granted in part sub nom. Elk Grove Unified Sch. Dist. v. Newdow, 124 S. Ct. 384 (Oct. 14, 2003).

115. E.g., Raich v. Ashcroft, 352 F.3d 1222 (9th Cir. 2003) (invoking the Supreme Court's language in United States v. Lopez, 514 U.S. 549 (1995), and United States v. Morrison, 529 U.S. 598 (2000), to cast doubt on the validity of federal drug laws in a way that likely would not command five votes on the Court); United States v. McCoy, 323 F.3d 1114 (9th Cir. 2003) (similarly invoking these cases while invalidating a federal pomography law).

116. See Vikram David Amar, Lower Court Obedience and the Ninth Circuit, 7 Gresn BaG 2d (forthcoming 2004).

117. Southwest Voter Registration Educ. Project v. Shelley, 344 F.3d 914, 919 (9th Cir. 2003) (en banc). 
persons who over the past few decades have favored "splitting" the Circuit, or dividing it up into administrative "divisions," have often stressed the fact that the Ninth Circuit is unique among federal courts of appeal in its inability to have regular complete en banc hearings where all the active judges of the Circuit come together in a single panel. ${ }^{118}$ But the recall episode demonstrates that the limited en banc mechanism in place in the Ninth Circuit since 1980 , whereby eleven judges rehear cases originally heard by three judges, can work well to quickly rein in a somewhat unrepresentative three-judge panel ruling.

En banc hearings are superior to three-judge panel hearings in controversial cases for two reasons. First, more heads are better than three. (That is why the highest appellate courts in the state and federal judiciaries typically have between five and nine seats.) Second, an additional hearing often can sharpen the presentation of the issues. Both these virtues were showcased in the recall en banc case. Importantly, as soon as the initial shock of the three-judge ruling subsided, lawyers, commentators andmost crucially - judges on the en banc panel used the week leading up to the en banc oral argument to focus sharply on the best way to understand the Bush v. Gore ruling and its (non)applicability to California's situation. Although it is but one data point, the success of the en banc process in this case undercuts at least to some extent the notion that the Circuit is inherently too large and too disparate to act cohesively when it needs to. ${ }^{119}$

But even as the Ninth Circuit deserves some kudos, it deserves some blame as well. After all, the election was held up for eight long days. That is a large percentage of a campaign that itself was only some fifty days long once all the candidates were qualified. Many people have speculated that the original three-judge ruling hurt Davis because he had momentum at that time and was slowed down by the uncertainty over the election date. ${ }^{120}$ Moreover, some people have suggested that voters who were angry at the three-judge panel took it out on Democratic players in the recall episode. ${ }^{121}$ We will never know how much.

One better course would have been for the three-judge panel, as soon as any of its members upon reviewing the briefs suspected that the election could be delayed, to refer the case automatically to all active members of the court to vote on whether to convene an en banc panel. That is, once any of the three judges to whom the case was assigned believed that Bush $v$.

118. See generally John B. Oakley, Comparative Analysis of Alternative Plans for the Divisional Organization of the Ninth Circuit, 34 U.C. Davis L. REv. 483, app. A (2000).

119. Thus, the Ninth Circuit showed its better side last September. And it did so truly in publicin a nationally televised proceeding. Let us hope more Courts of Appeals, and the Supreme Court, begin to regularly televise their proceedings so that the nation's classroom can expand.

120. See, e.g., the remarks of Garry South and Larry Grisolano at the IGS Conference described supra note 94.

121. Id. 
Gore even might justify relief, that momentous question should have been kicked upstairs to an en banc process, even without the three-judge panel ever having to come out with a ruling on the merits. Such a route would have saved time and spared litigants and voters substantial emotional and logistical turmoil. The Federal Rules of Appellate Procedure (FRAP) do have provisions for immediate en banc review ${ }^{122}$ (as opposed to rehearing en banc). 1 cannot imagine a more appropriate case for invoking such a process. A completely collegial and well-operating court might have tried to explore this preferable alternative.

1.

\section{Bush v. Gore Sucks.}

The key legal question posed by the ACLU's punch-card machine challenge was: What, exactly, does Bush v. Gore stand for? Let us begin with what it cannot stand for, which is what the three-judge panel of the Ninth Circuit read it to stand for-namely, the idea that the Equal Protection Clause of the Fourteenth Amendment invalidates any statewide election where different kinds of voting machinery throughout the state may lead to nontrivial differential error rates across counties. Bush v. Gore cannot stand for that principle because the majority opinion for the Court explicitly disavowed such a principle, saying that the question presented was decidedly "not whether local entities... may develop different systems for implementing elections." "23 Unless we are prepared to say that voting equipment is not part of a "system for implementing elections," (which it would seem to be), then the three-judge panel's identification of Bush v. Gore's core principle seems dubious.

Even putting aside this specific language by the Court, the three-judge panel's reading wouldn't make much sense of Bush $v$. Gore as a whole. We know that a majority of the Court thought that the manual recounts unfolding in Florida - whereby individual vote talliers in each county were using different criteria from those being used in other counties to determine how to read a ballot-violated the Equal Protection Clause of the Fourteenth Amendment by treating voters in some counties differently than voters in other counties. ${ }^{124}$ But we also know, because the Court said so early in its opinion, that in Florida there were many thousands of votes that the initial machine counts did not pick up because some (but not all) counties used

122. The FRAP authorize the judges of the Courts of Appeals to hear or rehear exceptional cases en banc. In particular, FRAP 35 authorizes a majority of active judges in a circuit to "order that an appeal or other proceeding be heard or reheard by the court of appeals en banc." FED. R. APP. P. 35 (emphasis added). The Rule then mentions a process by which parties can seek an en banc hearing, but nowhere states that such a request by a party is a necessary predicate to the court's power to convene an en banc hearing. Id. at 35(a).

123. Bush v. Gore, 531 U.S. 98, 108 (2000).

124. Id. at 109. 
the old punch-card machines. ${ }^{125}$ Indeed, the hand counting underway in Florida that the Court halted was itself an attempt to make the voices in each county equally strong. Not only did the Court not say that the disparate rate of machine-uncounted votes was the constitutional equality problem that rendered Florida's scheme unconstitutional, ${ }^{126}$ the Court said that the one eure-a manual recount-under existing Florida law to redress that problem was itself barred by the Equal Protection Clause. ${ }^{127}$

According to the Court, the core question in Bush v. Gore was "whether the use of standardless manual recounts violates the Equal Protection and Due Process Clauses." ${ }^{28}$ At a minimum, then, the standardless aspect of the recount going on in Florida was a key part of the equal protection violation found by the Court. Either the standardless aspect of the recount was the entirety of the equal protection problem or it was enough of an equal protection problem that it outweighed the other (and unstated) equal protection problem presented by the differential vote count error rates across counties due to disparate machinery. Either way, the standardless recount aspect surely is one of the "present circumstances" to which the case purported to be explicitly limited. ${ }^{129}$

Why would the standardlessness of the recounts being undertaken pose a constitutional problem? There are a few related reasons. To begin with, the recounts being undertaken in Florida were being done manually. That matters a great deal, because people who count votes by hand may make "mistakes" on account of political motivations. Machine errors of the kind foreseen in California, even if predictably skewed in favor of or against particular groups or parties, may pose a different question than do mistakes made by individual persons with possible political motivations. ${ }^{130}$ Put simply, the most plausible way to understand Bush v. Gore is by

125. Id. at 103-04.

126. If this intrastate disparity had been viewed as a distinct equal protection problem, one might have expected the Court to say so explicitly and to explain that Florida's solution--while laudable to the extent that it tried to redress (or avoid) an equal protection problem-created more problems than the violation it sought to solve. Instead, the Court simply said that Florida's solution was the problem.

127. Bush, 531 U.S. at 110.

128. Id. at 103; see also Einer Elhauge, Rewire This Circuit, WALL St. J., Sept. 17, 2003, at A26.

129. Bush, 531 U.S. at 109 ("Our consideration is limited to the present circumstances, for the problem of equal protection in election processes generally presents many complexities."). Of course, a higher court's admonition that its ruling is "limited" to present circumstances should not, and cannot, lead a lower court to construe the higher court ruling as having been fashioned out of some illicit resultoriented motive merely to advance the interests of one of the parties. But such an admonition to a lower court should move the lower court judge to find the narrowest, most fact-specific, but still principled way to read the decision. In this instance, that should have led the three-judge panel of the Ninth Circuit to narrow the case to the standardless manual recount scenario.

130. Equal protection law often treats a law that creates a disparate impact, even predictable disparate impact, very differently than one motivated by an invidious intent. And unlike the Florida situation, there were no allegations of invidious motive in California--that is, no one alleged that California planned to use outdated punch-card machines in some but not all counties in order to hurt the demographic or political groups located in the punch-card jurisdictions. 
reference to the concern shared by many people in the country-and seemingly by a large majority of Justices in Washington, D.C.- that Democratic and Republican county elections officials might try to take advantage of the broad discretion state law gave them to hand count votes to accomplish a partisan result.

Moreover, it bears noting that what was going on in Florida was a recount. The distinction between an initial count and a recount is critical, because by the time a recount occurs everyone knows that each miscounted vote (whether miscounted by design or by negligence) may be a big deal. In Florida-and thus in the country-it was clear by the time of the recounts that the margin of victory in a national presidential election, remarkably enough, was going to be a few hundred votes one way or another. The situation confronted by the Supreme Court was thus not simply one in which various Florida county officials could manipulate votecounting standards; it was one in which the manipulators pretty much knew how many votes they needed to steal in order to change the outcome.

These two features-manual recounts being done at a time when a few votes are known to matter-limit the scope of the Bush v. Gore decision and explain well why standardlessness posed a real problem to the Court. In California last September, of course, we did not have a recount situation, much less a standardless manual recount situation. If the punchcard machines had failed to read votes, and if the election had been extremely close, California purported to have in place a set of statewide standards to conduct a manual recount that should have avoided the problem of overly broad discretion that plagued Florida. For these reasons, the threejudge panel was guilty of extreme exaggeration in saying that "plaintiffs" claim presents almost precisely the same issue as the Court considered in Bush"131 and that the plaintiffs' claim "mirrors the one" in Bush v. Gore. ${ }^{132}$

But the ultimate fault for the mistakes of the three-judge panel really lies with the Supreme Court itself. Whether due to the tremendous time pressure under which it was written or for other reasons entirely, Bush v. Gore is very far from a model of judicial clarity or craftsmanship. If the three-judge panel of the Ninth Circuit had trouble figuring out exactly what the animating principle of Bush v. Gore ought to be viewed as, the three judges are part of a large club.

The primary reason for this-the most direct explanation for lower court confusion-is that the Supreme Court senselessly chose not to be explicit about things in Bush v. Gore. Indeed, the Court never explained why broad discretion was so problematic in these circumstances. Instead, it made the ridiculous assertion that Florida's decision to give latitude to each

131. Southwest Voter Registration Educ. Project v. Shelley, 344 F.3d 882, 895 (9th Cir. 2003), vacated, 344 F.3d 913 (9th Cir. 2003).

132. Id. at 894 . 
county to craft its own rules was "arbitrary" within the meaning of constitutional doctrine. ${ }^{133}$ I have elsewhere explained why giving counties the power to implement standards rather than rules in this setting, to take account of different demographics and economics in the various locales, is anything but arbitrary. ${ }^{134}$ But for now, let me add that Bush v. Gore is one of a number of cases that misuses minimum rationality review in an analytically dishonest way, and in a way that leads judges like those on the three-judge pancl to characterize California's interest in sticking to its timeline as "arbitrary." The three-judge panel's reasoning was surely flawed, but not nearly so flawed as the Court's.

What the Supreme Court should have said (once it made the grave mistake to accept review in the case and rule in Bush's favor) to explain and defend its (not altogether obvious) ruling is not that giving discretion is arbitrary, but that giving discretion is dangerous when people might be trying to steal elections. But such an honcst discussion would have impugned the participants in the Florida debacle, and the Court wanted to avoid personalizing the case. Yet in avoiding a personal insult, the Court commits a dangerous doctrinal one, and one that ends up disrupting many more millions of lives.

This type of problem arose in another landmark decision also affecting the Presidency. In United States v. Nixon, ${ }^{135}$ the Court likewise wanted to reach a result that was in fact driven by its views about a particular person, but chose to write an opinion that was not personalized. The result was a ruling by the Court that made dubious separation of powers doctrine, so that the Court could avoid offending Richard Nixon with an opinion that focused on his specific misdeeds. ${ }^{136}$ The Court's handiwork in Nixon helped lead to a flawed Independent Counsel Act that warped Washington law and politics for years. I only pray that Bush v. Gore's negative ramifications end with California's recall episodc.

133. 531 U.S. at 134.

134. See Vikram David Amar \& Alan E. Brownstein, Bush v. Gore and Article II: Pressured Judgment Makes Dubious Low, 48 FED. LAw. 27, 28-29 (2001).

135. 418 U.S. 683 (1974).

136. See Akhil Reed Amar, Nixon's Shadow, 83 MinN. L. Rev. 1405 (1999). 